\title{
Penerapan Model CA-Markov Untuk Prediksi Perubahan Penggunaan Lahan Di Sub-DAS Bila Tahun 2036
}

\author{
Reza Asra ${ }^{1}$, Muh Faisal Mappiasse ${ }^{2}$, Andi Ayu Nurnawati ${ }^{3}$ \\ ${ }^{1,3}$ Program Studi Agroteknologi, Universitas Muhammadiyah Sidenreng Rappang, Sulawesi Selatan, Indonesia. \\ ${ }^{2}$ Program Studi Kehutanan, Universitas Muslim Maros, Sulawesi Selatan, Indonesia.
}

*Email: ${ }^{1}$ rezaasraahmad@gmail.com, ${ }^{2}$ muhfaisalm331@gmail.com, ${ }^{3}$ ayunurnawati@gmail.com

\begin{abstract}
Abstrak
Sub-DAS Bila diindikasikan akan mengalami konversi lahan hutan menjadi ladang berpindah seiring perkembangan kebutuhan lahan saat ini. Tujuan penelitian ini untuk melihat pola perubahan penggunaan lahan dari tahun 2006 sampai dengan 2016 serta prediksinya tahun 2036 melalui penerapan model CA-Markov yang terdapat pada perangkat lunak Idrisi. Pola perubahan penggunaan lahan tahun 1996-2016 di sub-DAS Bila menunjukkan penurunan luasan signifikan pada penggunaan lahan hutan lahan kering primer sebesar $10,94 \%$ dan semak belukar sebesar $24,12 \%$. Sementara luasan pertanian lahan kering campur semak meningkat signifikan sebesar $24,33 \%$ dan hutan lahan kering sekunder sebesar 10,64\%. Begitu pula hasil simulasi prediksi penggunaan lahan tahun 2036, hutan lahan kering primer diprediksi berkurang seluas $10,2 \%$, semak belukar diprediksi berkurang $7,15 \%$, sedangkan hutan lahan kering sekunder diprediksi bertambah 8,63\%, permukiman diprediksi bertambah 4,62\%, pertanian lahan kering campur semak diprediksi bertambah 5,64\%. Penerapan model CA-Markov untuk memprediksi penggunaan lahan menunjukan nilai Kstandard 0,9 dinyatakan bahwa pemodelan diterima secara ilmiah.
\end{abstract}

Keywords : CA-Markov; Perubahan Penggunaan Lahan; Sub-DAS Bila.

\section{Pendahuluan}

Daerah Aliran Sungai (DAS) Bila merupakan DAS hulu yang bermuara di danau Tempe. Setiap tahun, bagian hilir atau danau Tempe mengalami masalah yakni banjir. Penyebab banjir di danau Tempe diakibatkan oleh daerah resapan air yang mengalami konversi lahan yang tidak memperhatikan pola penggunaan lahan yang memiliki fungsi sebagai daerah penyangga resapan air dan berdampak pada terjadinya erosi dan banjir. Erosi tentu mempercepat proses pendangkalan pada danau Tempe. Hal ini juga dikemukakan dalam Ikrima et al (2016) bahwa selain banjir di danau Tempe, juga terjadi pendangkalan danau yang diakibatkan oleh banyaknya sedimentasi yang terangkut dari hulu DAS. Selanjutnya danau Tempe diprediksikan mengalami peningkatan sedimentasi sebesar $15-20 \mathrm{~cm}$ per tahun. Peningkatan sedimentasi mengakibatkan meluapnya danau Tempe pada musim hujan yang luasannya mencapai 30.000 ha dan pada musim kering menurun menjadi 1.000 ha sehingga luasan tangkapan danau menjadi berkurang.

DAS Bila terdiri dari 3 sub-DAS yaitu sub-DAS Bila, sub-DAS Bungin dan sub-DAS Cenrana. Sub-DAS Bila termasuk dalam bagian hulu dari DAS Bila. Bagian hulu berperan sebagai kawasan penyangga (buffer) yang didominasi oleh hutan dengan topografi yang berbukit dan bergelombang. Kawasan penyangga di sub-DAS Bila adalah tempat ideal dalam menangkap air. Akar pohon dalam hutan mampu menyerap air sedangkan humus juga mampu menahan laju air. Sehingga menjaga kelestarian hulu DAS Bila yakni sub-DAS Bila mampu mengurangi masalah banjir dan pendangkalan danau.

Perubahan tutupan dan penggunaan lahan dapat diakibatkan oleh faktor alam serta aktivitas manusia (Sajikumar dan Remya, 2015). Dalam pelaksanaan pembangunan, Perubahan penggunaan lahan tidak dapat dihindari, begitupun di sub-DAS Bila. Faktor yang berperan penting dalam penggunaan lahan lebih banyak dipengaruhi oleh aktivitas manusia. Perubahan bisa terjadi karena adanya keinginan manusia untuk memenuhi kebutuhannya yang makin meningkat jumlahnya serta meningkatnya hasrat untuk perbaikan mutu kehidupannya. Dinamika perubahan jumlah penduduk seperti pada saat ini menyebabkan terjadinya konversi penggunaan lahan yang cukup besar dan mengakibatkan berubah fungsi. Misalnya dari hutan menjadi lahan pertanian atau perkebunan dan dari lahan pertanian menjadi kawasan pemukiman dan industri (Prabowo et al, 2017). Dengan demikian, sub-DAS Bila dapat diindikasikan akan mengalami konversi lahan seiring dengan perkembangan kebutuhan lahan manusia saat ini.

Perubahan penggunaan lahan dapat dianalisis dengan pemanfaatan penginderaan jauh berupa data citra satelit dan dikelola melalui sistem informasi geografis. Perubahan penggunaan lahan secara keruangan dapat dilakukan dengan cara mengkaji perubahan penggunaan lahan antara lain menghitung luas perubahan penggunaan lahan, tingkat perubahan penggunaan lahan, menganalisis 
pola perubahan dan pemodelan (Susilo, 2011). Pemanfaatan pemodelan adalah sebuah cara dalam mengkaji fenomena yang terjadi di dunia nyata. Pemodelan dapat meganalisis dan memprediksi pola perubahan penggunaan lahan. salah satunya dengan menggunakan LCM (Land Change Modeler).

Penggunaan LCM melalui penerapan model CAMarkov adalah salah satu cara dalam memprediksi perubahan penggunaan lahan. CA (Cellular Automata) adalah suatu metode komputasi berdasarkan prinsip ketetanggaan sel (neighbourhood) untuk memprediksi sistem dinamis yang bergantung pada aturan sederhana dan berkembang hanya dengan menurut aturan tersebut dari waktu ke waktu (Wardani et al, 2016). Rantai Markov (Markov Chain) dan proses Markov adalah salah satu bidang yang paling mendasar dari studi tentang probabilitas, yang saat ini juga telah mulai berkembang dalam ilmu spasial, dan saat ini banyak diterapkan di bidang penelitian perubahan tata guna lahan (land use change) (Baja, 2012).

Prediksi penggunaan lahan di sub-DAS Bila melalui model CA-Markov diharapkan mampu memberikan gambaran secara spasial sehingga perencanaan wilayah yang disusun sesuai dengan pola perubahan penggunaan lahan. Tujuan dilakukannya penelitian ini adalah untuk melihat pola perubahan penggunaan lahan dari tahun 2006 sampai dengan 2016 serta prediksinya pada tahun 2036 dengan menggunakan Land Change Modeler (LCM) melalui penerapan model CA-Markov yang terdapat pada perangkat lunak Idrisi Selva. Dari hasil pemodelan tersebut diperoleh perubahan penggunaan lahan tahun 2036.

\section{Metodologi}

Penelitian ini dilakukan pada wilayah Sub-DAS Bila. Sub-DAS Bila berada di antara koordinat $119^{\circ} 55^{\prime} 0^{\prime \prime}$ $120^{\circ} 10^{\prime} 0^{\prime \prime}$ BT dan $3^{\circ} 33^{\prime} 20^{\prime \prime}-3^{\circ} 53^{\prime} 20^{\prime \prime}$ LS. Sub-DAS Bila mempunyai luas sebesar 54.511,09 Ha.

Bahan dalam penelitian ini berupa data. Data yang digunakan yaitu data primer berupa hasil groundcheck dilapangan yang dilakukan pada tahun 2016. Selain itu ada data sekunder berupa data citra satelit Landsat 5 tahun 1996, 2006 dan Landsat 8 tahun 2016 dengan Path 114 Row 62 dan path 114 Row 63 yang diunduh melalui laman situs earthexplorer.usgs.gov, peta batas DAS tahun 2011 skala 1:100.000 yang diperoleh dari Balai Pengelolaan Daerah Aliran Sungai Pompengan-Jeneberang, selain itu digunakan juga data Peta Rupabumi Indonesia skala 1:250.000. Bahan penelitian ini kemudian dianalisis melalui perangkat lunak (software) Idrisi Selva 17, ArcMAP 10.3 dan Microsoft Office. Sedangkan untuk kepentingan survey lapangan (groundcheck) digunakan GPS, kamera dan alat tulis.

\subsection{Analisis perubahan penggunaan lahan}

Penelitian ini diawali dengan melakukan tahap persiapan yaitu menghasilkan peta penggunaan lahan tahun 1996, 2006 dan 2016. Data citra yang telah diunduh selanjutnya dilakukan penggabungan citra (row 62 dan row 63), pemotongan citra berdasarkan lokasi penelitian sesuai dengan batas luar peta subDAS Bila, serta koreksi geometrik untuk retifikasi (pembetulan) agar citra sesuai dengan koordinat rupa bumi yang ditetapkan. Setelah dilakukan koreksi, dilakukan interpretasi secara visual dengan memperhatikan pola, rona, tekstur dan warna pada citra. Sehingga didapatkan klasifikasi penggunaan lahan masing masing yaitu peta penggunaan lahan tahun 1996, 2006 dan tahun 2016.

\subsection{Uji akurasi Interpretasi citra}

Akurasi interpretasi citra dengan melakukan survey lokasi (groundcheck) untuk membandingkan hasil interpretasi citra dengan keadaan yang ada dilapangan. Dilakukan uji akurasi klasifikasi citra ini dengan tujuan untuk mengetahui seberapa besar keakuratan interpretasi citra dapat diterima. Pada penelitian ini, hasil interpretasi peta penggunaan lahan tahun 2016 akan diuji dengan groundcheck lapangan yang telah dilakukan pada tahun 2016 yang dinyatakan dalam presentase overall accuracy (OA) dengan persamaan berikut :

$$
O A=\frac{x}{n} \times 100 \%
$$

dimana

$\mathrm{x}=$ jumlah nilai diagonal matriks

$\mathrm{n}=$ jumlah sampel matriks

Sampel groundcheck pada penelitian yang telah ditetapkan sebanyak 153 titik yang harus sesuai dengan keadaan lapangan. Tingkat keakuratan interpretasi citra yang dapat diterima menurut Lillesand et al (1993) yaitu $85 \%$ yang dapat diinput dalam ilustrasi tabel confussion matriks (Sutanto, 1994) pada tabel 1 berikut ini.

Tabel 1. Confussion Matriks

\begin{tabular}{|c|c|c|c|c|c|}
\hline & \multicolumn{4}{|c|}{ Data Acuan (Pengecekan Lapangan) } & \multirow{2}{*}{$\begin{array}{l}\text { Total } \\
\text { Kolom }\end{array}$} \\
\hline & & $\mathrm{A}$ & $\mathrm{B}$ & $\mathrm{C}$ & \\
\hline \multirow{3}{*}{$\begin{array}{c}\text { Data Hasil } \\
\text { Klasifikasi } \\
\text { Citra }\end{array}$} & A & $\mathrm{Xn}$ & & & $\mathrm{Xk}+$ \\
\hline & $\mathrm{B}$ & & & & \\
\hline & $\mathrm{C}$ & & & Xkk & \\
\hline Total Baris & & $\mathrm{X}+\mathrm{k}$ & & & $\mathrm{N}$ \\
\hline
\end{tabular}

Setelah interpretasi dianggap akurat, maka didapatkan penggunaan lahan tahun 2016 aktual. Penggunaan lahan tahun 2016 aktual akan digunakan untuk membandingkan penggunaan lahan tahun 2016 hasil proyeksi CA-Markov.

\subsection{Prediksi perubahan penggunaan lahan tahun 2036}

Tahap utama penelitian ini adalah memprediksi penggunaan lahan dengan memodelkan perubahan penggunaan lahan. Simulasi model dijalankan dengan modul Cellular Automata Markov Chain (CA-Markov) yang merupakan perpaduan antara Markov Chain dan Multi-Objective Land Allocation (MOLA). Simulasi model dilakukan dalam 2 tahapan. Tahap pertama yaitu menghasilkan proyeksi penggunaan lahan tahun 2016 
dengan mensimulasikan perubahan penggunaan lahan tahun 1996 dan tahun 2006 yang digunakan untuk validasi keakuratan model. Selanjutnya tahap kedua yang menghasilkan penggunaan lahan tahun 2036 diperoleh dengan membandingkan perubahan yang terekam tahun 1996 dan 2016 dengan tab change analysis.

Metode proyeksi perubahan penggunaan lahan ini diasumsikan sama atau serupa pada perubahan penggunaan lahan di masa yang akan datang dengan perubahan penggunaan lahan masa yang lalu (Deng et al, 2009). Perubahan penggunaan lahan juga didasarkan pada kelas penggunaan lahan periode sebelumnya dan penggunaan lahan tetangganya (neighborhood). Modul Markov Chain menghasilkan transitional/probability area matrix yakni matriks transisi perubahan dari tahun sebelumnya ke tahun yang diprediksikan. Persamaan Markov dibangun menggunakan distribusi penggunaan lahan pada awal dan akhir pengamatan yang tergambarkan dalam suatu vektor (matriks satu kolom), serta sebuah matriks transisi (transition matrix) (Trisasongko et al, 2009). Hubungan ketiga matriks tersebut dapat ilustrasikan sebagai berikut:

$$
\begin{aligned}
& \text { MLC . Mt }=\text { Mt+1 } \\
& {\left[\begin{array}{lll}
\text { LCuu } & \text { LCua } & \text { LCuw } \\
\text { LCau } & \text { LCaa } & \text { LCaw } \\
\text { LCwu } & \text { LCwa } & \text { LCww }
\end{array}\right]\left[\begin{array}{c}
U t \\
A t \\
W t
\end{array}\right]=\left[\begin{array}{c}
U t+1 \\
A t+1 \\
W t+1
\end{array}\right]}
\end{aligned}
$$

Dimana Ut mempresentasikan peluang setiap titik terklarifikasikan sebagai kelas U pada waktu t. LCua menunjukkan peluang suatu kelas $U$ menjadi kelas lainnya pada rentang waktu tertentu (Trisasongko et al, 2009). Ilustrasi Matriks transisi ditunjukkan dalam Tabel 2 berikut ini

\begin{tabular}{|c|c|c|c|c|}
\hline \multirow{2}{*}{$\begin{array}{l}\text { Penggunaan } \\
\text { Lahan } 1996\end{array}$} & \multicolumn{4}{|c|}{ Penggunaan Lahan 2016} \\
\hline & Pit2 & Pit2 & & Pzt2 \\
\hline Pit1 & Xii & …........ & .............. & …......... \\
\hline Pit1 & …… & Xii & .......... & ……. \\
\hline .......... & ........... & ........... & ........... & .......... \\
\hline Pzt1 & ........... & ........... & ........... & Xii \\
\hline
\end{tabular}

Tabel 2. Ilustrasi Transitional/Probability Area Matrix

Pit1 : tipe penggunaan lahan ke-i pada tahun $\mathrm{t} 1$

t1 : tahun ke-1 (1996)

Pit2 : tipe penggunaan lahan ke-i pada tahun $\mathrm{t} 2$

t2 : tahun ke-2 (2016)

$\mathrm{Z}$ : jumlah tipe penggunaan lahan

Xii : luas perubahan penggunaan lahan ke-i periode tahun $\mathrm{t} 1-\mathrm{t} 2$

Langkah selanjutnya adalah prediksi perubahan (change prediction) dengan menggunakan rantai markov untuk mendapatkan prediksi penggunaan lahan tahun 2036 dan prediksi penggunaan lahan tahun 2016. Namun, untuk keakuratan prediksi penggunaan lahan tahun 2036 bergantung pada hasil validasi model.

\subsection{Validasi Model}

Validasi model dimaksudkan untuk mengetahui seberapa besar keakuratan proyeksi yang kita lakukan. Uji validasi dilakukan dengan membandingkan simulasi prediksi penggunaan lahan tahun 2016 dengan penggunaan lahan tahun 2016 aktual. Menurut Jensen (1996), uji validasi diukur dengan Kappa Index of Agrement (nilai kappa) sebagai berikut.

$$
k=\frac{N \& \sigma_{i=1}^{z} x_{i i}-\sigma_{i=1}^{z}\left(x_{i+}^{x} * x_{+}\right)}{N^{2}-\sigma_{i=1}^{z}\left(x_{i+1}^{i} * x_{+}\right)} .
$$

$\mathrm{K} \quad$ : nilai Kappa

Xii : luas tipe penggunaan lahan ke-i hasil simulasi yang bersesuaian dengan luas tipe penggunaan lahan ke-i hasil observasi

$\mathrm{Xi}+$ : luas tipe penggunaan lahan ke-i hasil simulasi

$\mathrm{X}+\mathrm{i}$ : luas tipe penggunaan lahan ke-i hasil observasi

$\mathrm{N}$ : jumlah luas semua tipe penggunaan lahan

$\mathrm{Z} \quad$ : jumlah tipe penggunaan lahan

Tool validate dalam Idrisi Selva digunakan untuk menghitung nilai kappa. Nilai kappa menentukan hasil simulasi bisa dikatakan sesuai baik dalam hal luas maupun sebaran spasialnya atau tidak. Setelah dianggap sesuai, pemodelan untuk prediksi penggunaan lahan di tahun 2036 dapat dilakukan.

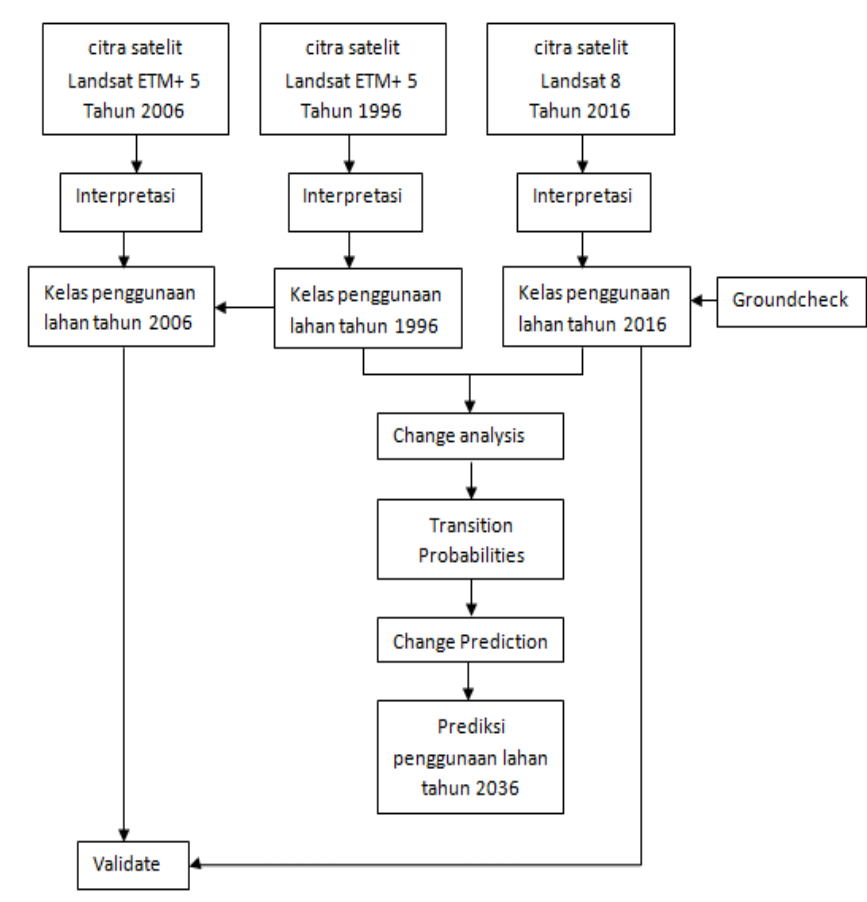

Gambar 1. Alur Penelitian

\section{Hasil}

Lokasi sub-DAS Bila meliputi tiga kabupaten. Pembagian luas wilayah sub-DAS Bila diantaranya 
kabupaten Enrekang yakni kecamatan Maiwa Atas seluas 6.185,69 ha, kabupaten Wajo seluas 4.368,65 ha yang berada di kecamatan Maniangpajo dan sebagian besar berada di wilayah kabupaten Sidenreng Rappang seluas 43.956,75 ha yang meliputi tiga keamatan yaitu kecamatan Pitu Riase, kecamatan Pitu Riawa, dan kecamatan Dua Pitue.Sub-DAS Bila mempunyai luas sebesar 54.511,09 Ha yang dapat dilihat pada tabel 3 berikut ini.

Tabel 3: Pembagian Wilayah Sub-DAS Bila

\begin{tabular}{cllc}
\hline No & KABUPATEN & KECAMATAN & luas (ha) \\
\hline \multirow{3}{*}{1} & \multirow{3}{*}{ Sidrap } & Kec. Pituriase & $24.415,48$ \\
& & Kec. Pituriawa & $14.381,23$ \\
2 & \multirow{2}{*}{ Enrekang } & Kec. Duapitue & $5.160,04$ \\
3 & Wajo & Kec. Maiwa Atas & $6.185,69$ \\
\hline \multicolumn{5}{c}{ Jumlah } \\
\hline
\end{tabular}

\subsection{Hasil analisis perubahan penggunaan lahan tahun 1996-2016}

Hasil interpretasi citra satelit Landsat ETM+ 5 tahun 1996, tahun 2006 dan citra satelit Landsat 8 tahun 2016 serta hasil observasi yang dilakukan dilapangan untuk penggunaan lahan pada sub-DAS Bila, penggunaan lahan pada Sub-DAS Bila dibedakan atas sembilan kelas yaitu hutan lahan kering primer, hutan lahan kering sekunder, padang rumput, permukiman, pertanian lahan kering campur semak, sawah, semak belukar, tanah terbuka, dan tubuh air.

Hasil interpretasi penggunaan lahan tahun 2016 kemudian dilakukan uji ketelitian dari hasil klasifikasi yang didapatkan dengan membandingkan interpretasi penggunaan lapangan dengan melakukan survey lapangan (groundcheck) tiap penutupan lahan yang ditentukan.Dari sembilan kelas hasil interpretasi penggunaan lahan tahun 2016, tiap kelas dilakukan pengecekan sebanyak 17 titik untuk membuktikan ketelitian interpretasi peta yang sudah dibuat. Penentuan titik survey lapangan dengan memperhatikan kemampuan aksebilitas peneliti dalam mengambil titik koordinat. Uji ketelitian ini bertujuan untuk mengetahui persentase kepercayaan data hasil interpretasi citra Landsat yang diperoleh berdasarkan tabel confusion matrix, Adapun tabel confusion matrix dapat disajikan pada Tabel 4.

Tabel 4 Confusion matrix titik sampel masing-masing kelas penggunaan lahan tahun 2016

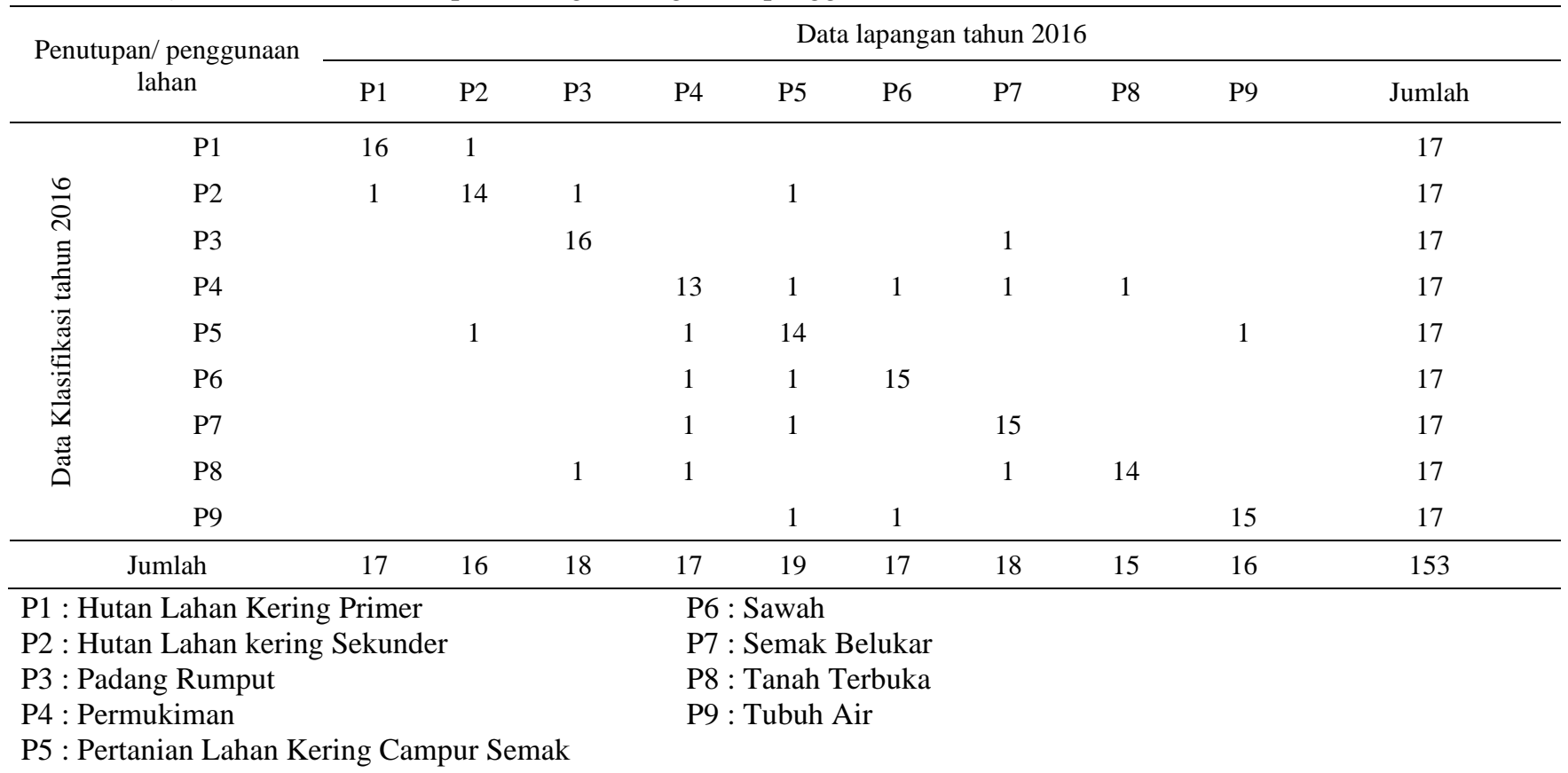

Hasil uji akurasi dari tabel confusion matrix yaitu dari 153 titik survey lapangan, sebanyak 132 titik yang sesuai dengan hasil interpretasi. Presentase keakuratan yaitu $132 / 153=86,27 \%$ yang menunjukkan bahwa hasil interpretasi dan klasifikasi citra yang dilakukan dapat diterima sesuai dengan tingkat ketelitian yang disarankan minimal $85 \%$ (Lillesand et al, 1993). Dengan demikian, dapat diasumsikan bahwa klasifikasi citra satelit Tahun
1996 dan Tahun 2016 dapat digunakan untuk melakukan skenario dan validasi penggunaan lahan hingga Tahun 2036.

Pola penggunaan lahan tahun 1996-2016 mengalami perubahan penggunaan lahan dinamis yang dapat dilihat Pada Tabel 5. Hasil analisis pada tahun 1996, terlihat bahwa hutan lahan kering primer dan semak belukar merupakan penggunaan lahan yang mendominasi wilayah di sub-DAS Bila. 
Namun, kedua penggunaan lahan ini mengalami penurunan luas selama periode tahun 1996 sampai tahun 2016. Sedangkan penggunaan lahan berupa pertanian lahan kering campur semak mengalami peningkatan luas selama periode tahun 1996 sampai tahun 2016. Dari pola penggunaan lahan dapat dilihat bahwa kecenderungan manusia memanfaatkan hutan dan semak belukar untuk digunakan sebagai lahan pertanian. Sementara potensi lahan kritis dan erosi akan terjadi apabila perubahan lahan yang bervegetasi rapat seperti hutan baik primer maupun sekunder ataupun hutan tanaman berubah menjadi lahan yang bervegetasi kurang rapat seperti pertanian lahan kering (Kubangun et al, 2016).

Tabel 5 Perubahan Tutupan Lahan Dari Tahun 1996-2016

\begin{tabular}{|c|c|c|c|c|c|c|}
\hline \multirow{3}{*}{ TUTUPAN LAHAN } & \multicolumn{4}{|c|}{ PERIODE } & \multirow{2}{*}{\multicolumn{2}{|c|}{$\begin{array}{l}\text { PERUBAHAN DARI } \\
\text { TAHUN } 1996 \text { - } 2016\end{array}$}} \\
\hline & \multicolumn{2}{|c|}{ TAHUN 1996} & \multicolumn{2}{|c|}{ TAHUN 2016} & & \\
\hline & LUAS & $\%$ & LUAS & $\%$ & LUAS & $\%$ \\
\hline Hutan Lahan Kering Primer & $19.695,33$ & 36,13 & $13.730,87$ & 25,19 & $-5.964,46$ & $-10,94$ \\
\hline Hutan Lahan Kering Sekunder & $1.713,90$ & 3,14 & $7.515,68$ & 13,79 & $5.801,78$ & 10,64 \\
\hline Padang Rumput & $2.042,08$ & 3,75 & $2.450,14$ & 4,49 & 408,06 & 0,75 \\
\hline Permukiman & 314,93 & 0,58 & 364,44 & 0,67 & 49,5 & 0,09 \\
\hline Pertanian Lahan Kering Campur Semak & $4.108,10$ & 7,54 & $17.373,27$ & 31,87 & $13.265,17$ & 24,33 \\
\hline Sawah & $3.920,82$ & 7,19 & $3.914,91$ & 7,18 & $-5,91$ & $-0,01$ \\
\hline Semak Belukar & $20.797,31$ & 38,15 & $7.650,85$ & 14,04 & $-13.146,46$ & $-24,12$ \\
\hline Tanah Terbuka & 598,76 & 1,10 & 191,19 & 0,35 & $-407,57$ & $-0,75$ \\
\hline Tubuh Air & $1.319,86$ & 2,42 & $1.319,74$ & 2,42 & $-0,12$ & 0 \\
\hline TOTAL & $54.511,09$ & 100 & $54.511,09$ & 100 & 0 & 0 \\
\hline
\end{tabular}

\subsection{Prediksi Penggunaan Lahan Tahun 2036}

Sebelum melakukan prediksi penggunaan lahan pada tahun 2036, dilakukan analisis proyeksi penggunaan lahan tahun 1996 hingga tahun 2006 untuk memprediksi penggunaan lahan tahun 2016. Proyeksi ini bertujuan untuk memetakan prediksi tahun 2016 agar dapat dapat divalidasi dengan peta penggunaan lahan tahun 2016 aktual yang telah dibuat sebelumnya. Hasil validasi akan memunculkan nilai kappa yang bisa diperoleh melalui tools Validate pada idrisi selva.

Nilai validasi yang tergambar dalam nilai kappa memiliki tingkat kesesuaian antara jumlah baris dan kolom maksimal 1,00. Nilai Kappa > 0,75 menunjukkan adanya kesepakatan/kesesuaian yang sangat baik, nilai Kappa $=0,04-0,75$ kesepakatan/kesesuaian baik dan apabila nilai Kappa < 0,40 maka kesepakatan/kesesuaian dinyatakan lemah (Bhisma, 1997). Hasil validasi antara penggunaan lahan tahun 2016 aktual dengan penggunaan lahan hasil prediksi dapat dilihat pada gambar 3 berikut.

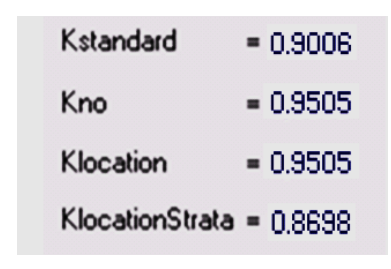

\section{Gambar 3. Hasil Tool Validate}

Hasil validasi antara prediksi tahun 2016 terhadap interpretasi tahun 2016 menunjukkan nilai kappa (Kstandard) 0,9. Hal ini berarti antara hasil skenario dengan penutupan lahan sebenarnya memiliki kesesuaian yang sangat baik dalam hal penyebaran luasan maupun spasialnya hingga $90 \%$.

Dengan demikian, penggunaan lahan pada tahun 1996 dan tahun 2016 dapat digunakan untuk memproyeksikan penggunaan lahan tahun 2036. Proyeksi dari tahun 2016 ke tahun 2036 didasarkan pada keadaan penutupan/penggunaan lahan tahun 2016 dalam trasition probabilities yang dihasilkan dari proses markov antara tahun 1996 dan tahun 2016. Nilai transition probabilities dapat dilihat pada gambar 4 berikut ini. 


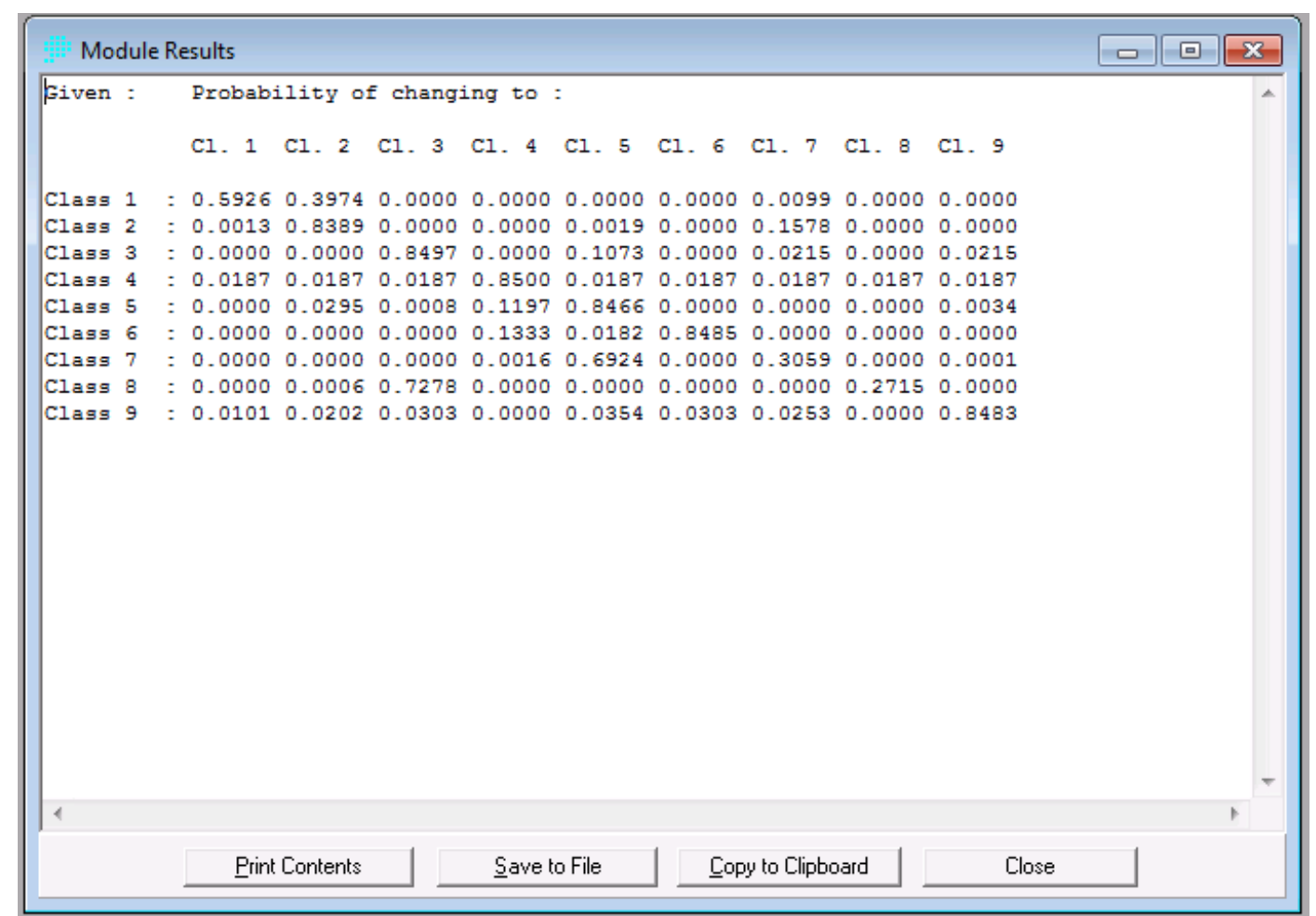

Gambar 4. Nilai transition probabilities

Nilai transition probabilities atau probabilitas transisi hasil dari Markov Chain digunakan sebagai dasar untuk menentukan lokasi yang diproyeksikan akan mengalami perubahan oleh CA (Cellular
Automata). Hasil Prediksi penggunaan lahan tahun 2036 dengan input data peta penggunaan lahan tahun 1996 dan tahun 2016 dapat dilihat pada gambar 5 berikut.

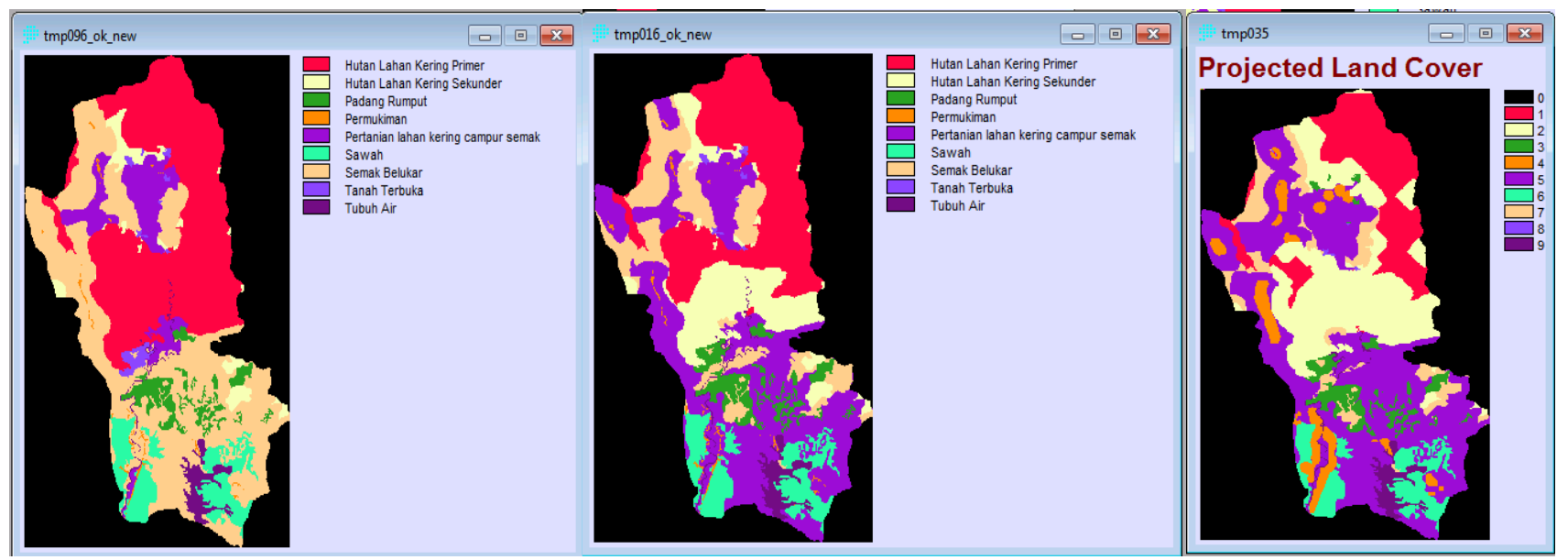

Gambar 5. Peta Perubahan Penggunaan Lahan di aplikasi idrisi selva

Hasil dari prediksi penggunaan lahan pada tahun 2036 kemudian ditumpangsusunkan (overlay) dengan penggunaan lahan pada tahun 2016 untuk melihat seberapa besar tingkat perubahan yang terjadi sebagaimana diperlihatkan pada tabel 6 berikut. 
Tabel 6. Perubahan Penutupan Lahan Tahun 2016-2036

\begin{tabular}{|c|c|c|c|c|c|c|}
\hline \multirow{3}{*}{ TUTUPAN LAHAN } & \multicolumn{6}{|c|}{ PERIODE } \\
\hline & \multicolumn{2}{|c|}{ TAHUN 2016} & \multicolumn{2}{|c|}{ TAHUN 2036} & \multicolumn{2}{|c|}{$\begin{array}{c}\text { PERUBAHAN } \\
\text { 2016-2036 }\end{array}$} \\
\hline & LUAS & $\%$ & LUAS & $\%$ & LUAS & $\%$ \\
\hline $\begin{array}{l}\text { Hutan Lahan Kering } \\
\text { Primer }\end{array}$ & $13.730,87$ & 25,19 & $8.173,91$ & 14,99 & $-5.556,96$ & $-10,2$ \\
\hline $\begin{array}{l}\text { Hutan Lahan Kering } \\
\text { Sekunder }\end{array}$ & $7.515,68$ & 13,79 & $12.221,31$ & 22,42 & $4.705,63$ & 8,63 \\
\hline Padang Rumput & $2.450,14$ & 4,49 & $2.285,06$ & 4,19 & $-165,08$ & $-0,3$ \\
\hline Permukiman & 364,44 & 0,67 & 2881,04 & 5,29 & $2.516,60$ & 4,62 \\
\hline $\begin{array}{l}\text { Pertanian Lahan Kering } \\
\text { Campur Semak }\end{array}$ & $17.373,27$ & 31,87 & 20447,203 & 37,51 & $3.073,93$ & 5,64 \\
\hline Sawah & $3.914,91$ & 7,18 & $3.367,24$ & 6,18 & $-547,67$ & -1 \\
\hline Semak Belukar & $7.650,85$ & 14,04 & $3.756,35$ & 6,89 & $-3.894,50$ & $-7,15$ \\
\hline Tanah Terbuka & 191,19 & 0,35 & 59,43 & 0,11 & $-131,76$ & $-0,24$ \\
\hline Tubuh Air & $1.319,74$ & 2,42 & $1.319,53$ & 2,42 & $-0,21$ & 0 \\
\hline TOTAL & $54.511,09$ & 100 & 54511,09 & 100 & 0,00 & 0 \\
\hline
\end{tabular}

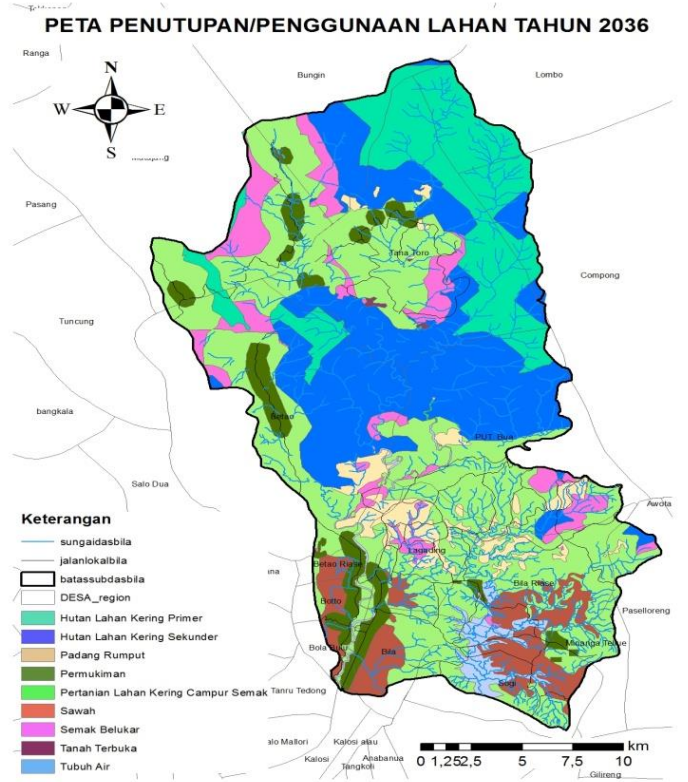

Gambar 6. Peta Prediksi Penggunaan Lahan Sub-DAS Bila Tahun 2036

Pada Tabel 6 dapat dilihat hasil prediksi penggunaan lahan pada tahun 2036 menunjukkan perubahan yang cukup pesat dibandingkan dengan penggunaan lahan 2016. Prediksi penggunaan lahan yang mengalami penurunan luasan yang cukup signifikan ialah hutan lahan kering primer, sedangkan penggunaan lahan yang mengalami peningkatan yang ialah hutan lahan kering sekunder dan pertanian lahan kering campur semak. Hal tersebut mengindikasikan bahwa dari proyeksi kedepan akan berkurang lahan hutan yang dialihfungsikan menjadi lahan pertanian/perkebunan. Perlu dilakukan manajemen lahan dengan baik untuk mengatur jenis penggunaan lahan tertentu agar dapat menekan terjadinya penurunan kualitas lahan.

Pemanfaatan lahan tanpa memperhatikan kaidah konservasi akan mengakibatkan lahan kritis yang rentan mengalami erosi dan banjir di musim penghujan dan mengalami kekeringan di musim kemarau. Apalagi ketika lahan hutan yang menjadi penyangga akan terus menerus berkurang demi kebutuhan ekonomi. Semntara dalam hutan tropis, tingginya pertumbuhan penduduk dan permintaan untuk komoditas pangan sebagai akibat dari kawasan 
hutan semakin berkurang (Jiang et al, 2012). Dengan demikian, dalam upaya mempertahankan lahan yang lestari dan berkelanjutan, kegiatan pemanfaatan lahan bukan hanya berorientasi pada ekonomi, namun juga berorientasi pada lingkungan.

\section{Kesimpulan}

Pola perubahan penggunaan lahan tahun 1996-2016 di sub-DAS Bila menunjukkan penurunan luasan yang signifikan pada penggunaan lahan hutan lahan kering primer sebesar 5.964,46 Ha $(10,94 \%)$ dan semak belukar sebesar 13.146,46 Ha (24,12\%). Sementara luasan pertanian lahan kering campur semak meningkat signifikan sebesar 13.265,17 Ha $(24,33 \%)$ dan hutan lahan kering sekunder sebesar 5.801,78 Ha $(10,64 \%)$.

Hasil simulasi prediksi penggunaan lahan menggunakan model CA-Markov tahun 2036, perubahan masing - masing 9 penggunaan lahan adalah hutan lahan kering primer diprediksi berkurang seluas 5.556,96 Нa $(10,2 \%)$, hutan lahan kering sekunder diprediksi bertambah seluas 4.705,63 (8,63\%), padang rumput diprediksi berkurang seluas 165,08 Ha (0,3\%), permukiman diprediksi bertambah seluas 2.516,60 Ha $(4,62 \%)$, pertanian lahan kering campur semak diprediksi bertambah seluas $3.073,93 \mathrm{Ha}(5,64 \%)$, sawah diprediksi berkurang seluas $547,67 \mathrm{Ha}(1 \%)$, semak belukar diprediksi berkurang seluas 3.894,50 Ha (7,15\%), tanah terbuka diprediksi berkurang $131,76 \mathrm{Ha}(0,24 \%)$, dan tubuh air diprediksi berkurang seluas $0,21 \mathrm{Ha}(0,001 \%)$.

Penerapan model CA-Markov untuk memprediksi penggunaan lahan di sub-DAS Bila tahun 2036 mempunyai kesesuaian/kesepakatan sangat baik berdasarkan uji validasi menggunakan metode Kappa Index of Agreement menunjukan nilai Kstandard 0,9 dari skala 0-1. Dapat dinyatakan bahwa peta panggunaan lahan hasil pemodelan diterima secara ilmiah.

\section{Daftar Pustaka}

Baja, S., 2012. Perencanaan Tata Guna Lahan dalam Pengembangan Wilayah: Pendekatan Spasial dan Aplikasinya. Andi Yogyakarta, Yogyakarta.

Bhisma M. 1997. Prinsip Dan Metode Riset Epidemiologi. UGM Press, Yogyakarta.

Deng, J.S., K. Wang, Y. Hong, and J.G. Qi., 2009. Spatio temporal dynamics and evolution of land use change and landscape pattern in response to rapid urbanization. Landscape and Urban Planning. 92, 187-198.

Ikrima, S., Oteng, H., Yayat, H., 2016. Analisis Debit Aliran Sungai Das Bila Sulawesi Selatan. Jurnal Sumber Daya Air, 12 (2), 117 - 130.

Jensen, J. R., 1996. Introductory Digital Image Processing : A Remote Sensing Prespective. Prentice Hall, Upper Saddler River.

Jiang, D., Huang, Y., Zhuang, D., Zhu, Y., Xu, X., \& Ren, H., 2012. A Simple Semi-Automatic Approach for Land Cover Classification from Multispectral Remote Sensing Imagery. PloS one, 7(9), e45889.

Kubangun, S.H., Oteng, H., dan Komarsa, G., 2016. Model Perubahan Penutupan/Penggunaan Lahan Untuk Identifikasi Lahan Kritis Di Kabupaten Bogor, Kabupaten Cianjur, Dan Kabupaten Sukabumi. Majalah Ilmiah Globë, 18 (1), 21-32.

Lillesand, T. M., Kiefer, R. W., Dulbahri, Suharsono, P., Hartono, Suharyadi, \& Sutanto., 1993. Penginderaan Jauh dan Interpretasi Citra. Gadjah Mada University, Yogyakarta.
Prabowo, D.P., Syamsul, B., Bagus, S.W., 2017. Prediksi Penggunaan Lahan Dan Pola Berdasarkan Citra Landsat Multi Waktu Dengan Land Change Modeler (LCM) Idrisi Selva 17: Studi Kasus Sub DAS Hulu. Jurnal Pendidikan Geografi, 22 (1), 32-48.

Sajikumar, N., \& Remya, R. S., 2015. Impact of land cover and land use change on runoff characteristics. Journal of Environmental Management, $\quad 161, \quad 460-468 . \quad$ https://doi.org/10. 1016/j.jenvman.2014.12.041S

Susilo, B., 2011. Pemodelan Spasial Probabilistik Integrasi Markov Chain Dan Cellular Automata Untuk Kajian Perubahan Penggunaan Lahan Skala Regional Di Provinsi Daerah Istimewa Yogyakarta. Gea, 11 (2), 163-178.

Sutanto, 1994. Penginderaan Jauh Jilid 2. Gadjah Mada University Press, Yogyakarta.

Trisasongko, B.H., D.R. Panuju, L.S. Iman, Harimurti, A.F. Ramly, V. Anjani, dan H. Subroto., 2009. Analisis Dinamika Konversi Lahan di Sekitar Jalur Tol Cikampek. Publikasi Teknis DATIN. Kementrian Negara Lingkungan Hidup, Jakarta.

Wardani, D.W., Projo, D., Bowo S., 2016. Kajian Perubahan Penggunaan Lahan Berbasis Cira Satelit Penginderaan Jauh Resolusi Menengah Dengan Metode Multi Layer Perceptron Dan Markov Chain. Majalah Geografi Indonesia. 30 (1), 9-18. 